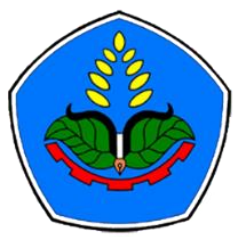

AGROPROSS

National Conference

Proceedings of Agriculture

\section{Proceedings: \\ Peran Teaching Factory Di Perguruan Tinggi Vokasi Dalam Mendukung Ketahanan Pangan Pada Era New Normal}

Tempat : Politeknik Negeri Jember

Tanggal : 8-9 Juli 2020

\section{Publisher:}

Agropross, National Conference Proceedings of Agriculture

ISBN : 978-623-94036-6-9

DOI : 10.25047/agropross.2020.5

\title{
Pengaruh Kondisi Kapasitas Lapang Yang Berbeda Terhadap Pertumbuhan Vegetatif Varietas Kacang Hijau (Vigna radiata L.)
}

\author{
Author(s): Mela Apriyani ${ }^{(1)^{*}}$; Amarullah ${ }^{(1)}$; Aditya Murtilaksono ${ }^{(1)}$ \\ (1) Program Studi Agroteknologi, Fakultas Pertanian, Universitas Borneo Tarakan \\ * Corresponding author: melaapriyani28@gmail.com
}

\begin{abstract}
Mung beans are planted with the ability to tolerate drought. Easy cultivation techniques that make green beans have business opportunities in the field of agribusiness. Nevertheless, the growth of mung bean plants is influenced by varieties. The lack of use of superior varieties of marginal land will result in a lack of plant growth, because currently agricultural land is increasingly shifting to less fertile land, one of which is the lack of availability of water in the soil for plant growth. Therefore, this study was conducted to determine varieties and conditions of field capacity that are suitable for the vegetative growth of mung beans. The study was conducted at the Screen House and Plant Protection Laboratory with factorial RAK consisting of factors of mung bean varieties (Vima-1, Vima-2, Vima-3 and Kutilang) and conditions of field capacity (100\% KL, 80\% $K L, 60 \% \mathrm{KL}, 40 \% \mathrm{KL}$ and $20 \% \mathrm{KL}$ The results of the observations were analyzed in a variety of ways and tested further with Duncan's Multiple Range Test (DMRT) level of $5 \%$. The results showed that the interaction between varieties and field capacity affected the diameter of mung bean stems. Other vegetative: Vima-3 varieties obtained the highest average number of leaves, greenish leaves and leaf area, the highest average plant height, stem diameter, number of leaves and leaf area were obtained at $80 \%$ KL conditions. Vima-3 gets the best vegetative growth while the field capacity that is suitable for the vegetative growth of mung beans is $80 \% \mathrm{KL}$
\end{abstract}

Keyword:

field capacity;

varieties;

Vigna radiata

L.;

\footnotetext{
Kata Kunci:

\section{ABSTRAK}

Kacang hijau merupakan tanaman dengan kemampuan toleran terhadap kekeringan. Teknik budidaya yang

Kapasitas

Lapang; mudah menjadikan kacang hijau memiliki peluang usaha dalam bidang agrobisnis. Meskipun demikian, pertumbuhan tanaman kacang hijau dipengaruhi oleh varietas. Kurangnya penggunaan varietas unggul pada lahan marginal akan mengakibatkan kurangnya pertumbuhan tanaman, sebab saat ini lahan pertanian semakin

Varietas;

Vigna radiata bergeser ke arah lahan yang kurang subur salah satunya kurangnya ketersediaan air di dalam tanah bagi pertumbuhan tanaman. Oleh karena itu, penelitian ini dilakukan guna mengetahui varietas dan kondisi

$\mathrm{L}$. kapasitas lapang yang sesuai bagi pertumbuhan vegetatif kacang hijau. Penelitian dilaksanakan di Screen House dan Laboratorium Perlindungan Tanaman dengan RAK faktorial yang terdiri dari faktor varietas kacang hijau (vima-1, vima-2, vima-3 dan Kutilang) dan faktor kondisi kapasitas lapang $(100 \% \mathrm{KL}, 80 \% \mathrm{KL}$, $60 \% \mathrm{KL}, 40 \% \mathrm{KL}$ dan $20 \% \mathrm{KL}$. Hasil pengamatan dianalisis ragam dan diuji lanjut dengan Duncan's Multiple Range Test (DMRT) taraf 5\%. Hasil penelitian menunjukkan interaksi antara varietas dan kapasitas lapang berpengaruh terhadap diameter batang kacang hijau. Interaksi tidak berpengaruh terhadap pertumbuhan vegatatif lainnya. Varietas Vima-3 memperoleh rata-rata jumlah daun, kehijauan daun dan luas daun paling tinggi. Rata-rata tinggi tanaman, diameter batang, jumlah daun dan luas daun tertinggi diperoleh pada kondisi $80 \%$ KL. Berdasarkan hasil penelitian disimpulkan bahwa varietas Vima-3 memperoleh pertumbuhan vegetatif paling baik sedangkan kondisi kapasitas lapang yang sesuai bagi pertumbuhan vegetatif kacang hijau adalah $80 \% \mathrm{KL}$.
} 


\section{PENDAHULUAN}

Kacang hijau (Vigna radiata L.) merupakan komoditas yang termasuk dalam family Leguminoceae dan merupakan salah satu komoditas pangan yang banyak dikonsumsi. Teknik budidaya yang relatif mudah menjadikan tanaman kacang hijau memiliki peluang usaha dalam bidang agrobisnis karena dapat diolah menjadi berbagai macam bentuk seperti bubur, kue bahkan dapat dijadikan sayur. Biji maupun tepung kacang hijau banyak digunakan dalam berbagai bentuk pangan, seperti bubur, roti dan mie. Sementara itu, kecambah kacang hijau (tauge) yang banyak mengandung vitamin E digunakan untuk sayur (Purwono, Purnawati 2013).

Menurut data Badan Pusat Statistik (2016) produksi kacang hijau di Indonesia pada tahun 2012 yakni 284.257 ton, setelah itu mengalami penurunan produksi tahun 2013 menjadi 204.670 ton dan mengalami peningkatan pada tahun 2014 hingga 2015 yakni 244.589 ton dan 271.463 ton meskipun demikian produksi masih dikatakan mengalami penurunan. Turunnya produksi kacang hijau disebabkan oleh mutu kacang hijau yang rendah karena penggunaan varietas unggul yang masih kurang. Sedangkan peningkatan produksi kacang hijau dikarenakan teknik budidaya kacang hijau yang relatif mudah serta memiliki daya adaptasi yang tinggi salah satunya yakni pada kondisi kekurangan air.

Tanaman yang mengalami kekeringan akan merespon baik secara fisiologi, biokimia maupun molekuler. Respon fisiologi yakni dengan penurunan proses fotosintesis yang mengakibatkan pertumbuhan dan hasil tanaman terhambat sedangkan respon biokimia yakni dengan penyesuaian osmotik yang dihasilkan dari senyawa metabolit baru sehingga dapat menekan terjadinya reactive oxygen species (ROS) yang dapat merusak jaringan tanaman seperti DNA, lipid, dan protein.

Penelitian dilakukan dengan kondisi kapasitas lapang yang berbeda dimulai dengan pemberian air yang kurang dari kapasitas lapang hingga pemberian air yang optimal dari kapasitas lapang (KL). Hasil penelitian Sianipar et al. (2013) tanaman kacang hijau yang diberi perlakuan sinar gamma dan cekaman kekeringan dengan menggunakan kapasitas lapang menunjukkan cekaman kekeringan berpengaruh nyata terhadap volume akar, jumlah polong berisi per tanaman, dan bobot biji per tanaman dengan rata-rata nilai tertinggi terdapat pada kondisi $100 \%$ KL yakni $19,92 \mathrm{~mL}$, 2,03 polong dan 1,64 g sedangkan rata-rata nilai terendah volume akar terdapat pada kondisi $80 \%$ KL yakni 9,33 mL, jumlah polong berisi per tanaman dan bobot biji per tanaman terendah terdapat pada kondisi $40 \% \mathrm{KL}$ dengan nilai rata-rata 1,57 polong serta 1,19 g. Cekaman kekeringan dengan tingkat pemberian air $40 \% \quad \mathrm{KL}$ menunjukkan tanaman masih dapat tumbuh dan beradaptasi dengan baik namun hasil produksinya rendah.

Peningkatkan produksi kacang hijau dapat dilakukan dengan intensifikasi yakni menanam varietas unggul berdaya hasil tinggi baik secara kuantitas maupun kualitas serta mampu beradaptasi terhadap kondisi lingkungan setempat. Ada beberapa varietas kacang hijau unggul hasil pemuliaan yang dilepas oleh Balai Penelitian Tanaman Aneka Kacang dan Umbi (BALITKABI) untuk dikembangkan, diantaranya Kutilang, Vima-1, Vima-2 dan Vima-3. Umumnya, stabilitas hasil dari suatu varietas yang unggul untuk suatu daerah belum tentu menunjukkan keunggulan yang sama di daerah lain, karena faktor perbedan iklim, topografi dan cara tanam.

Berdasarkan hal tersebut untuk meningkatkan produksi kacang hijau dalam hal budidaya perlu digunakannya 
beberapa varietas unggul dan dalam usaha ekstensifikasi, penggunaan lahan pertanian akan bergeser dari lahan yang subur ke lahan marginal salah satunya lahan kering dimana kurangnya ketersediaan air sehingga terjadinya cekaman kekeringan yang mengakibatkan produksi kacang hijau mengalami penurunan. Oleh karena itu, penelitian ini dilakukan dengan menggunakan empat macam varietas kacang hijau dan kondisi kapasitas lapang yang berbeda untuk mengetahui varietas kacang hijau yang dapat memperoleh hasil pertumbuhan fase vegetatif kacang hijau terbaik pada berbagai kondisi kapasitas lapang dan pemberian air yang tepat bagi pertumbuhan tanaman kacang hijau.

\section{BAHAN DAN METODE}

Penelitian dilaksanakan pada bulan Desember 2018 hingga Februari 2019. Penelitian dilaksanakan di Screen House dan Laboratorium Perlindungan Tanaman Fakultas Pertanian Universitas Borneo Tarakan. Alat yang digunakan pada penelitian ini adalah cangkul, terpal, oven, timbangan digital, ayakan $2,8 \mathrm{~mm}$, meteran, timbangan analitik, botol kaca, jangka sorong, SPAD dan gelas ukur. Sedangkan bahan yang digunakan pada penelitian ini adalah 4 varietas benih kacang hijau (Vima-1, Vima-2, Vima-3 dan Kutilang), air, tanah, pupuk kandang sapi, pupuk Urea, pupuk SP-36, pupuk $\mathrm{KCl}$, alumunium foil, kertas label, kertas milimeter blok dan polibag ukuran $20 \times 50$ $\mathrm{cm}$.

Penelitian ini menggunakan Rancangan Acak Kelompok (RAK) dengan pola faktorial yang terdiri dari dua faktor yaitu: Faktor empat varietas kacang hijau dengan notasi (V) terdiri 4 taraf yaitu: V1=Vima-1, V2=Vima-2, V3=Vima-3 dan V4=Kutilang. Faktor kapasitas lapang (KL) dengan notasi (A) terdiri dari 5 taraf yaitu: $\quad \mathrm{A} 0=100 \% \quad \mathrm{KL}, \quad \mathrm{A} 2=60 \% \quad \mathrm{KL}$, $\mathrm{A} 4=20 \% \mathrm{KL}, \mathrm{A} 1=80 \% \mathrm{KL}$ dan $\mathrm{A} 3=40 \%$ KL.
Berdasarkan faktor perlakuan di atas diperoleh 20 kombinasi perlakuan diulang 3 kali masing-masing 1 sampel sehingga diperoleh 60 satuan percobaan dan setiap polibag percobaan terdiri dari satu tanaman yang dijadikan sebagai tanaman sampel.

Pelaksanaan penelitian dilakukan dengan cara pengambilan tanah sebagai media tanam yang sudah dikering udara selama \pm 7 hari, menentukan kadar air tanah dan kapasitas lapang, persiapan media tanam $10 \mathrm{~kg} /$ polibag, penanaman yakni sebanyak 2 benih per polibag yang kemudian 7 HST dilakukan penjarangan dengan menyisakan 1 tanaman yang pertumbuhannya paling baik dan seragam (Arsyadmunir 2016).

Kandungan air tanah dihitung dengan rumus sebagai berikut (Kurnia et al. 2006):

$$
\mathrm{KA}(\%)=\frac{\mathrm{A}-\mathrm{B}}{\mathrm{B}} \times 100 \%
$$

Keterangan:

$$
\begin{aligned}
\mathrm{KA}(\%)= & \text { Kandungan air tanah }(\%) \\
\mathrm{A}= & (\text { Berat tanah }+ \text { berat alumunium foil }) \\
& \text { sebelum dioven }- \text { berat alumunium } \\
& \text { foil }) \\
\mathrm{B}= & (\text { Berat tanah }+ \text { berat aluminuum foil }) \\
& \text { sesudah dioven }- \text { berat alumunium foil })
\end{aligned}
$$

Menetapkan berat air kapasitas lapang sebagai berikut (Campbell et al. 1986):

$$
\mathrm{KA}(\%)=\frac{\text { berat air }}{\%} \times 100
$$

Keterangan :

Berat tanah $=$ berat tanah yang digunakan $(\mathrm{g})$

Pemeliharaan dengan pemberian air yang sesuai dengan kapasitas lapang yang telah ditentukan yakni sebagai berikut; Pemberian air untuk 100\% KL adalah 994,79 g. Jadi, volume pemberian air dibawah kapasitas lapang dapat dikalikan dengan persentase kapasitas lapang maka: $80 \%=994,79 \mathrm{~g} \mathrm{x} 80 \%=795,83 \mathrm{~g}=796 \mathrm{~g}$ 
$60 \%=994,79 \mathrm{~g} \mathrm{x} 60 \%=596,87 \mathrm{~g}=597 \mathrm{~g}$ $40 \%=994,79 \mathrm{~g} \mathrm{x} 40 \%=397,91 \mathrm{~g}=398 \mathrm{~g}$ $20 \%=994,79 \mathrm{~g} \times 20 \%=198,95 \mathrm{~g}=199 \mathrm{~g}$

Pemupukan dilakukan pada umur 30 HST dengan dengan dosis anjuran yang digunakan yaitu pupuk Urea $100 \mathrm{~kg} / \mathrm{Ha}$, pupuk SP-36 $100 \mathrm{~kg} / \mathrm{Ha}$ dan pupuk $\mathrm{KCl} 75$ $\mathrm{kg} / \mathrm{Ha}$ (Purwono, Purwanti 2013) sehingga didapatkan hasil konversi (Urea 0,4 g/tanaman, $\quad$ SP-36 0,4 g/tanaman dan $\mathrm{KCl} 0,3 \mathrm{~g} /$ tanaman). Penyiangan dilakukan dua kali pada umur 14 HST dan 28 HST. Parameter pengamatan dilakukan mulai dari umur 14 hingga 35 HST yakni tinggi tanaman $(\mathrm{cm})$, diameter batang (cm), jumlah daun (helai), kehijauan daun (SPAD/Unit) dan luas daun $\left(\mathrm{cm}^{2}\right)$.

\section{HASIL DAN PEMBAHASAN}

Berdasarkan hasil analisis data secara statistik, varietas maupun kondisi kapasitas lapang berpengaruh nyata tetapi interaksi antara varietas dan kondisi kapasitas lapang tidak berpengaruh nyata terhadap pertumbuhan tinggi tanaman kacang hijau umur 14 hingga 35 HST sehingga uji DMRT taraf 5\% hanya dilakukan pada varietas maupun kondisi kapasitas lapang. Hasil penelitian mengenai pengaruh varietas dan kondisi kapasitas lapang terhadap tinggi tanaman kacang hijau umur 14 hingga 35 HST disajikan pada table berikut:

Tabel 1. Rata-rata Pertumbuhan Vegetatif Tanaman Akibat Pengaruh Varietas Kacang Hijau

\begin{tabular}{|c|c|c|c|c|c|c|c|}
\hline \multirow{2}{*}{$\begin{array}{c}\text { Parameter } \\
\text { Pengamatan }\end{array}$} & \multicolumn{4}{|c|}{ Varietas } & \multirow{2}{*}{$\begin{array}{c}\text { F } \\
\text { Hitung }\end{array}$} & \multirow{2}{*}{$\begin{array}{c}\text { F } \\
\text { Tabel } \\
5 \%\end{array}$} & \multirow{2}{*}{$\begin{array}{l}\text { DMRT } \\
\mathbf{5 \%}\end{array}$} \\
\hline & Vima-1 & Vima-2 & Vima-3 & Kutilang & & & \\
\hline \multicolumn{8}{|l|}{ Tinggi Tan. (cm) } \\
\hline 14 HST & $17,49 \mathrm{a}$ & $20,85 b$ & $19,35 \mathrm{ab}$ & $21,05 b c$ & $6,70^{*}$ & & 1,98 \\
\hline $21 \mathrm{HST}$ & $18,73 \mathrm{a}$ & $22,21 b c$ & $21,77 b$ & $23,23 \mathrm{bcd}$ & $9,50^{*}$ & & 1,94 \\
\hline 28 HST & $19,13 a$ & $22,76 b c$ & $22,52 b$ & $24,03 \mathrm{bcd}$ & $11,47^{*}$ & & 1,92 \\
\hline 35 HST & $19,59 \mathrm{a}$ & $23,09 \mathrm{bc}$ & $22,69 b$ & $24,47 \mathrm{bcd}$ & $11,10^{*}$ & & 1,91 \\
\hline \multicolumn{8}{|l|}{$\begin{array}{l}\text { Diameter Batang } \\
\text { (cm) }\end{array}$} \\
\hline 14 HST & $0,12 \mathrm{ab}$ & $0,13 b c$ & $0,11 \mathrm{a}$ & $0,15 \mathrm{c}$ & $3,62 *$ & & $\mathbf{0 , 0 2}$ \\
\hline $21 \mathrm{HST}$ & $0,14 \mathrm{ab}$ & $0,16 b c$ & $0,12 \mathrm{a}$ & $0,18 \mathrm{c}$ & $4,25 *$ & & $\mathbf{0 , 0 3}$ \\
\hline 28 HST & $0,18 \mathrm{a}$ & $0,19 a$ & $0,17 \mathrm{a}$ & $0,19 \mathrm{a}$ & $0,96^{\mathrm{tn}}$ & & tn \\
\hline 35 HST & $0,19 \mathrm{a}$ & $0,20 \mathrm{a}$ & $0,19 \mathrm{a}$ & $0,19 \mathrm{a}$ & $0,64^{\mathrm{tn}}$ & & tn \\
\hline \multicolumn{8}{|l|}{ Jml Daun (helai) } \\
\hline 14 HST & $0,27 \mathrm{ab}$ & $0,33 a b c$ & $0,80 \mathrm{~d}$ & $0,13 \mathrm{a}$ & $7,15^{*}$ & & $\mathbf{0 , 3 3}$ \\
\hline $21 \mathrm{HST}$ & $1,00 \mathrm{a}$ & $1,00 \mathrm{a}$ & $1,00 \mathrm{a}$ & $1,00 \mathrm{a}$ & $1,00^{\text {tn }}$ & 2,85 & tn \\
\hline 28 HST & $1,47 \mathrm{abc}$ & $1,40 \mathrm{ab}$ & $1,87 \mathrm{~d}$ & $1,33 \mathrm{a}$ & $4,88^{*}$ & & $\mathbf{0 , 3 3}$ \\
\hline 35 HST & $2,07 \mathrm{ab}$ & $2,00 \mathrm{a}$ & $2,47 \mathrm{c}$ & $2,07 \mathrm{ab}$ & $3,00 *$ & & $\mathbf{0 , 3 8}$ \\
\hline \multicolumn{8}{|l|}{$\begin{array}{l}\text { Kehijauan Daun } \\
\text { (N) }\end{array}$} \\
\hline $21 \mathrm{HST}$ & $29,15 \mathrm{a}$ & $33,22 \mathrm{abc}$ & $34,31 b c$ & $30,62 \mathrm{ab}$ & $5,31 *$ & & 4,11 \\
\hline 28 HST & $32,43 a$ & $36,39 b c$ & $36,62 \mathrm{bcd}$ & $34,76 b$ & $8,75^{*}$ & & 2,02 \\
\hline 35 HST & $36,51 \mathrm{a}$ & $39,24 b c$ & $39,55 \mathrm{bcd}$ & $37,74 b$ & $4,83 *$ & & 1,99 \\
\hline \multicolumn{8}{|l|}{ Luas Daun $\left(\mathrm{cm}^{2}\right)$} \\
\hline $21 \mathrm{HST}$ & $31,42 \mathrm{a}$ & $30,13 a$ & $35,79 \mathrm{a}$ & $30,76 a$ & $1,00^{\text {tn }}$ & & tn \\
\hline 28 HST & $51,11 \mathrm{a}$ & $45,16 \mathrm{a}$ & $69,67 \mathrm{a}$ & $54,21 \mathrm{a}$ & $2,06^{\mathrm{tn}}$ & & tn \\
\hline 35 HST & $83,67 \mathrm{a}$ & $78,19 \mathrm{a}$ & $120,06 a$ & $95,95 \mathrm{a}$ & $2,46^{\mathrm{tn}}$ & & tn \\
\hline
\end{tabular}

Keterangan :

* Angka yang diikuti oleh huruf sama dalam baris, tidak berbeda nyata berdasarkan Uji Duncan's pada taraf $5 \%$. tn=tidak nyata dan HST=hari setelah tanam. 
Tabel 1 menunjukkan rata-rata tinggi tanaman dan diameter batang paling tinggi diakibatkan karena penggunaan varietas Kutilang yakni $24,47 \mathrm{~cm}$ dan $0,18 \mathrm{~cm}$. Hasil penelitian ini tidak sejalan dengan hasil penelitian Nur et al. (2018) dimana varietas Kutilang memperoleh pertambahan tinggi tanaman paling rendah pada media tanam ultisol dibandingkan varietas Vima-1, Vima-2 dan Vima-3. Hal ini diduga disebabkan karena faktor lingkungan maupun genetik dimana Pratiwi et al. (2012) menyatakan bahwa pertumbuhan tanaman yang dipengaruhi oleh faktor lingkungan maupun genetik disebut dengan fenologi dimana hasil penelitian ini menunjukkan bahwa tanaman mengalami pertumbuhan yang diakibatkan karena faktor lingkungan yang tidak optimal dan juga karena sifat genetik tanaman. Selanjutnya, dengan penggunaan varietas Vima-3 mengakibatkan tanaman memiliki rata-rata jumlah dan kehijauan daun tanaman paling tinggi dari yakni 2,47 helai dan 39,55 N. Hal ini diduga karena varietas Vima-3 dapat beradaptasi pada kondisi lingkungan suboptimal. Hasil penelitian Nur et al. (2018) menunjukkan bahwa varietas Vima-3 memperoleh ratarata pertambahan jumlah daun paling tinggi pada media tanam ultisol yakni 3,60 helai. Trustinah el al. (2014) menyatakan bahwa varietas Vima-3 memiliki stabilitas diatas rata-rata dan beradaptasi pada lingkungan suboptimal.
Dugaan lain disebabkan karena varietas Vima-3 memiliki kemampuan beradaptasi pada kondisi lingkungan suboptimal mengakibatkan tanaman menyerap lebih banyak unsur hara $\mathrm{K}$ untuk bisa tetap mengalami pertumbuhan dan perkembangan dimana unsur K merupakan salah satu unsur hara yang mampu mempertahanakan turgor daun pada potensial air yang rendah, sehingga mencegah penutupan stomata. Hasil penelitian Rinaldi et al. (2012) menyatakan hasil analisis trichokompos kulit buah kopi dari Laboratorium analisis tanah menunjukkan bahwa kandungan $\mathrm{K}$ di trichokompos kulit buah kopi cukup tinggi yaitu sebesar $2,33 \%$ bila dibandingkan dengan kandungan unsur hara lainnya yang dimana tanaman yang memperoleh kalium yang cukup akan mampu mempertahanakan turgor daun pada potensial air yang rendah, sehingga mencegah penutupan stomata yang memungkinkan tanaman tetap memfiksasi $\mathrm{CO}_{2}$, meskipun dalam keadaan kadar air tanah yang rendah. Selanjutnya, pada saat stomata membuka akan terjadi akumulasi $\mathrm{K}+$ pada sel penjaga. Konsentrasi kalium yang tinggi dalam mesofil akan menurunkan potensial osmotik dan meningkatkan retensi air serta akan mengurangi laju transpirasi, sehingga dengan menyuplai kalium kehilangan air akan lebih rendah.

Tabel 2. Rata-rata Pertumbuhan Vegetatif Tanaman Akibat Pengaruh Kondisi Kapasitas Lapang Yang Berbeda

\begin{tabular}{|c|c|c|c|c|c|c|c|c|}
\hline \multirow{2}{*}{$\begin{array}{c}\text { Parameter } \\
\text { Pengamata } \\
n\end{array}$} & \multicolumn{5}{|c|}{ Kapasitas Lapang } & \multirow{2}{*}{$\begin{array}{c}F \\
\text { Hitung }\end{array}$} & \multirow{2}{*}{$\begin{array}{c}\text { F } \\
\text { Tabel } \\
\mathbf{5 \%}\end{array}$} & \multirow{2}{*}{$\begin{array}{c}\text { DMRT } \\
5 \%\end{array}$} \\
\hline & $100 \%$ & $80 \%$ & $60 \%$ & $40 \%$ & $20 \%$ & & & \\
\hline \multicolumn{9}{|l|}{$\begin{array}{l}\text { Tinggi Tan. } \\
\text { (cm) }\end{array}$} \\
\hline 14 HST & $21,21 b c$ & $21,74 \mathrm{c}$ & $19,36 \mathrm{~b}$ & $19,18 \mathrm{ab}$ & $16,94 \mathrm{a}$ & $7,09^{*}$ & & 2,26 \\
\hline 21 HST & $23,05 \mathrm{~cd}$ & $23,81 \mathrm{~d}$ & $21,15 \mathrm{abc}$ & $20,41 \mathrm{ab}$ & $19,02 \mathrm{a}$ & $7,72 *$ & & 2,22 \\
\hline 28 HST & $23,68 \mathrm{~cd}$ & $24,33 \mathrm{~d}$ & $21,73 \mathrm{abc}$ & $21,13 \mathrm{ab}$ & $19,68 \mathrm{a}$ & $7,50^{*}$ & & 2,19 \\
\hline 35 HST & $24,06 \mathrm{~cd}$ & $24,65 d$ & 22,03abc & $21,48 \mathrm{ab}$ & $20,09 a$ & $7,40^{*}$ & & 2,19 \\
\hline \multicolumn{9}{|l|}{ Diameter } \\
\hline Batang (cm) & & & & & & & & \\
\hline 14 HST & $0,14 b c$ & $0,15 \mathrm{c}$ & $0,12 \mathrm{ab}$ & $0,11 \mathrm{a}$ & $0,11 \mathrm{a}$ & $3,98^{*}$ & & $\mathbf{0 , 0 2}$ \\
\hline
\end{tabular}




\begin{tabular}{|c|c|c|c|c|c|c|c|}
\hline $21 \mathrm{HST}$ & $0,16 a$ & $0,16 a$ & $0,16 \mathrm{a}$ & $0,15 \mathrm{a}$ & $0,13 \mathrm{a}$ & $1,06^{\mathrm{tn}}$ & tn \\
\hline 28 HST & $0,20 \mathrm{bcd}$ & $0,19 b c$ & $0,18 \mathrm{~b}$ & $0,18 \mathrm{~b}$ & $0,15 \mathrm{a}$ & $3,20 *$ & $\mathbf{0 , 0 2}$ \\
\hline 35 HST & $0,20 \mathrm{a}$ & $0,20 \mathrm{a}$ & $0,20 \mathrm{a}$ & $0,19 a$ & $0,18 \mathrm{a}$ & $2,04^{\mathrm{tn}}$ & tn \\
\hline $\begin{array}{l}\text { Jml Daun } \\
\text { (helai) }\end{array}$ & & & & & & \multicolumn{2}{|c|}{2,61} \\
\hline 14 HST & $0,50 \mathrm{a}$ & $0,58 \mathrm{a}$ & $0,33 a$ & $0,42 \mathrm{a}$ & $0,08 \mathrm{a}$ & $2,50^{\operatorname{tn}}$ & tn \\
\hline $21 \mathrm{HST}$ & $1,00 \mathrm{a}$ & $1,00 \mathrm{a}$ & $1,00 \mathrm{a}$ & $1,00 \mathrm{a}$ & $1,00 \mathrm{a}$ & $1,00^{\mathrm{tn}}$ & tn \\
\hline $28 \mathrm{HST}$ & $1,50 \mathrm{abc}$ & $1,83 \mathrm{~cd}$ & $1,58 \mathrm{bcd}$ & $1,42 \mathrm{ab}$ & $1,25 \mathrm{a}$ & $3,16^{*}$ & 0,38 \\
\hline 35 HST & $2,17 \mathrm{abc}$ & $2,58 \mathrm{c}$ & $2,08 \mathrm{ab}$ & $2,08 \mathrm{ab}$ & $1,83 \mathrm{a}$ & $3,92 *$ & 0,43 \\
\hline $\begin{array}{l}\text { Kehijauan } \\
\text { Daun (N) }\end{array}$ & & & & & & & \\
\hline 21 HST & $29,80 \mathrm{a}$ & $30,77 \mathrm{a}$ & $32,63 a$ & $32,28 \mathrm{a}$ & $33,64 a$ & $2,45^{\mathrm{tn}}$ & tn \\
\hline 28 HST & $34,66 a$ & $34,74 \mathrm{a}$ & $35,15 \mathrm{a}$ & $34,52 \mathrm{a}$ & $36,18 \mathrm{a}$ & $0,85^{\mathrm{tn}}$ & tn \\
\hline 35 HST & $38,21 \mathrm{a}$ & $38,67 \mathrm{a}$ & $37,68 \mathrm{a}$ & $37,65 \mathrm{a}$ & $39,10 \mathrm{a}$ & $0,76^{\mathrm{tn}}$ & tn \\
\hline $\begin{array}{l}\text { Luas Daun } \\
\left(\mathrm{cm}^{2}\right)\end{array}$ & & & & & & & \\
\hline 21 HST & $39,54 d$ & $40,55 \mathrm{de}$ & $28,24 \mathrm{ab}$ & $28,51 \mathrm{abc}$ & $23,29 a$ & $3,97 *$ & 10,96 \\
\hline 28 HST & $64,63 \mathrm{bcd}$ & $78,79 d$ & $46,10 \mathrm{ab}$ & $47,20 \mathrm{abc}$ & $38,48 a$ & $4,04 *$ & 25,83 \\
\hline 35 HST & $\begin{array}{l}104,10 a b \\
\text { cd }\end{array}$ & $135,66 \mathrm{~d}$ & $83,92 \mathrm{abc}$ & $80,20 \mathrm{ab}$ & $68,46 a$ & $3,96^{*}$ & 42,02 \\
\hline
\end{tabular}

Tabel 3 menunjukkan kondisi kapasitas lapang memberikan pengaruh yang berbeda-beda terhadap pertumbuhan fase vegetatif tanaman kacang hijau yakni pada pertumbuhan tinggi tanaman, jumlah daun dan luas daun tanaman kacang hijau menunjukkan nilai rata-rata tertinggi yang disebabkan karena kondisi $80 \%$ KL yakni $24,65 \mathrm{~cm}, 2,58$ helai dan 135,66 $\mathrm{cm}^{2}$. Hal ini diduga karena kondisi $100 \%$ KL merupakan kondisi jenuh air yang menutupi ruang pori tanah sehingga absorbsi unsur hara menjadi terganggu. Hasil penelitian Marsha et al. (2014) menunjukkan rata-rata tinggi tanaman akibat waktu pemberian air setiap hari dengan volume air $100 \% \mathrm{KL}$ lebih rendah yakni $14,83 \mathrm{~cm}$ dari pada $80 \%$ KL yakni $16,05 \mathrm{~cm}$ yang disebabkan karena pada kondisi jenuh, seluruh ruang pori tanah terisi oleh air yang bergerak relatif cepat, sehingga dapat mencuci unsur-unsur hara yang dilaluinya sehingga tidak dapat diserap oleh akar tanaman. Selain itu, berdampak buruk bagi aerasi tanah, sehingga respirasi akar dan aktivitas mikrobia aerobik seperti bakteri amonifikasi dan nitrifikasi akan terganggu.
Oksigen sangat penting kaitannya dengan respirasi akar tanaman dan mikroorganisme tanah untuk mendapatkan energi yang selanjutnya dimanfaatkan oleh akar untuk menyerap unsur hara bagi pertumbuhan dan perkembangan tanaman.

Berbeda halnya dengan pertumbuhan diameter batang dimana nilai rata-rata tertinggi disebabkan karena kondisi 100\% KL yakni $0,20 \mathrm{~cm}$ yang kemudian mengalami penurunan diameter batang seiring rendahnya kadar air di dalam tanah. Hal ini disebabkan karena semakin rendah kadar air di dalam tanah mengakibatkan kebutuhan air bagi tanaman tidak tercukupi. Hasil penelitian Evita (2012) menunjukkan pemberian air pada kondisi $25 \%$ dan $50 \%$ kapasitas lapang menghasilkan tinggi tanaman lebih rendah dibandingkan dengan pemberian air pada kondisi $75 \%, 100 \%$ dan $125 \% \mathrm{KL}$ yakni $29,76 \mathrm{~cm}$ dan $34,88 \mathrm{~cm}$. Hal ini didukung oleh teori yang dikemukakan oleh Whigham, Minor (1978) dalam Laise et al. (2017) bahwa cekaman kekurangan air yang terjadi pada fase vegetatif mengakibatkan berkurangnya diameter batang dan tanaman menjadi lebih pendek. 
Data hasil pengamatan diameter batang tanaman kacang hijau yang telah dianalisis secara statistik menunjukkan interaksi antara varietas dan kapasitas lapang berpengaruh nyata pada umur 14 HST.

Tabel 3. Rata-rata Diameter Batang pada Umur 14 HST Akibat Pengaruh Interaksi Varietas Kacang Hijau dan Kapasitas Lapang

\begin{tabular}{cccccc}
\hline \multirow{2}{*}{$\begin{array}{c}\text { Varietas } \\
\text { (V) }\end{array}$} & \multicolumn{5}{c}{ Diameter Batang (cm) } \\
\cline { 2 - 6 } & $100 \%$ & $80 \%$ & $60 \%$ & $40 \%$ & $20 \%$ \\
\hline Vima-1 & $0,13 \mathrm{AB}$ & $0,13 \mathrm{AB}$ & $0,10 \mathrm{~A}$ & $0,13 \mathrm{AB}$ & $0,10 \mathrm{~A}$ \\
& $\mathrm{ab}$ & $\mathrm{ab}$ & $\mathrm{a}$ & $\mathrm{ab}$ & $\mathrm{a}$ \\
Vima-2 & $0,10 \mathrm{~A}$ & $0,17 \mathrm{~B}$ & $0,17 \mathrm{~B}$ & $0,10 \mathrm{~A}$ & $0,10 \mathrm{~A}$ \\
& $\mathrm{a}$ & $\mathrm{bc}$ & $\mathrm{b}$ & $\mathrm{a}$ & $\mathrm{a}$ \\
Vima-3 & $0,13 \mathrm{AB}$ & $0,10 \mathrm{~A}$ & $0,10 \mathrm{~A}$ & $0,10 \mathrm{~A}$ & $0,10 \mathrm{~A}$ \\
& $\mathrm{ab}$ & $\mathrm{a}$ & $\mathrm{a}$ & $\mathrm{a}$ & $\mathrm{a}$ \\
Kutilang & $0,20 \mathrm{C}$ & $0,20 \mathrm{C}$ & $0,10 \mathrm{~A}$ & $0,10 \mathrm{~A}$ & $0,13 \mathrm{AB}$ \\
& $\mathrm{c}$ & $\mathrm{c}$ & $\mathrm{a}$ & $\mathrm{a}$ & $\mathrm{ab}$ \\
\hline
\end{tabular}

Ket: Angka-angka yang diikuti oleh huruf kecil (a,b,c) yang sama arah vertikal dan huruf besar (A,B,C) yang sama arah horizontal tidak berbeda nyata pada taraf $\%$ DMRT.

Tabel 3 menunjukkan hasil interaksi antara varietas dan kondisi kapasitas lapang memberikan pengaruh yang nyata terhadap pertumbuhan diameter batang tanaman kacang hijau pada umur 14 HST dengan rata-rata diameter batang paling tinggi diperoleh dari interaksi antara varietas Kutilang dengan kondisi $100 \% \mathrm{KL}$ dan $80 \%$ KL yakni $0,20 \mathrm{~cm}$. Hal ini diduga varietas Kutilang dapat tumbuh pada kondisi tersebut baik dalam keadaan kondisi kapasitas lapang maupun dengan kondisi dibawah kapasitas lapang. Hasil penelitian Trustinah et al. (2014) menunjukkan bahwa varietas Kutilang dapat beradaptasi pada semua lingkungan.

\section{KESIMPULAN}

Berdasarkan hasil penelitian yang telah dilakukan dapat disimpulkan bahwa varietas vima-3 memberikan pertumbuhan tanaman paling baik dengan kondisi kapasitas lapang $80 \% \mathrm{KL}$, akan tetapi tidak interaksi antar keduanya tidak memberikan pengaruh yang nyata terhadap pertumbuhan vegetatif tanaman kacang hijau. Sedangkan varietas Kutilang dan kondisi kapasitas lapang $80 \% \quad \mathrm{KL}$ memberikan pengaruh interaksi terhadap pertumbuhan diameter bantang pada umur 14 HST.

\section{UCAPAN TERIMA KASIH}

Saya ucapkan terima kasih kepada bapak Ammarullah dan Aditya Murtilaksono sebagai pembimbing saya dan juga kepada rekan-rekan Fakultas Pertanian, Universitas Borneo Tarakan yang telah membantu dan memberikan saran dan masukan sehingga penelitian ini dapat terselesaikan dengan baik.

\section{DAFTAR PUSTAKA}

Arsyadmunir A. 2016. Periode Kritis Kekeringan Pada Pertumbuhan dan Produksi Kacang Hijau (Vigna radiate L.). Jurnal Agrovigor, 9(2), 132-140.

https://journal.trunojoyo.ac.id/agrovi gor/article/download/2319/1927

BPS. 2016. Produksi Kacang Hijau Menurut Provinsi (ton), 1993-2015. https://bps.go.id/linkTableDinamis/v iew/id/877 diakses tanggal 03 Oktober 2018 
Campbell GS, Jackson RD, Mortland MM, Nielsen DR, Chair AK. 1986. Methods of Soil Analysis. Madison, Wisconsin USA.

Evita. 2012. Pertumbuhan dan Hasil Kacang Tanah (Arachis hypogaea L.) Pada Perbedaan Tingkatan Kandungan Air. Jurnal Agroekoteknologi, 1(1), 1-7. https://onlinejournal.unja.ac.id/bioplante/article/v iew/1740/1127

Kurnia U, Agus F, Adimihardja A, Dariah A. 2006. Sifat Fisik Tanah dan Metode Analisisnya. http://balittanah.litbang.pertanian.go .id diakses tanggal 30 Oktober 2018.

Laise RA, Mestawaty AA, Tangge L. 2017. Respon Pertumbuhan Tanaman Cabai (Capsicum frutescens L.) Terhadap Cekaman Air Untuk Pemanfaatannya Sebagai Media Pembelajaran. Jurnal Elektronik Prodi Biologi, 5(1), 109-118. http://jurnal.untad.ac.id/jurnal/index. $\mathrm{php} / \mathrm{EBiol} /$ article/download/9373/74 48

Marsha DN, Aini N, Sumarni T. 2014. Pengaruh Frekuensi dan Volume Pemberian Air pada Pertumbuhan Tanaman Crotalaria mucronata Desv. Jurnal Produksi Tanaman, 2(8), 673-678. https://media.neliti.com/media/publi cations/128854-ID-pengaruhfrekuensi-dan-volumepemberian.pdf

Nur F, Wahidah BF, Afdal E. 2018. Pertumbuhan Berbagai Macam Varietas Tanaman Kacang Hijau (Phaseolus radiatus) pada Tanah
Ultisol.

Jurnal Teknosains, 12(2), 229-240.

http://journal.uinalauddin.ac.id/index.php/teknosains/ article/download/7601/6166

Pratiwi H, Rahmianna AA, Taufiq A. 2012. Perbandingan Fenologi Beberapa Varietas Unggul Kacang Hijau pada Pertanaman Awal Musim Hujan; Malang, Provinsi Jawa Timur. Prosiding Seminar Hasil Penelitian Tanaman Aneka Kacang dan Umbi 487-492.

http://balitkabi.litbang.pertanian.go.i $\mathrm{d} / \mathrm{wp}-$ content/uploads/2013/08/59_Herdin a-1.pdf

Purwono, Purnawati. 2013. Budidaya 8 Jenis Tanaman Unggul. Penebar Swadaya, Jakarta.

Rinaldi, Mapegau, S Maria F. 2012. Pengaruh Pemberian Trichokompos Kulit Buah Kopi dengan Kadar Air Tanah yang Berbeda terhadap Pertumbuhan Bibit Kakao (Theobroma cacao) di Polybag. Jurnal Bioplante, 1(3), 216-224. https://onlinejournal.unja.ac.id/bioplante/article/v iew/1752/1139

Sianipar J, P Lollie A, Putri, Ilyas S. 2013. Pengaruh Radiasi Sinar Gamma Terhadap Tanaman Kacang Hijau (Vigna radiata L.) Pada Kondisi Kekeringan. Jurnal Online Agroteknologi, 1(2), 136-148. https://media.neliti.com/media/publi cations/94364-ID-pengaruh-radiasisinar-gamma-terhadap-ta.pdf

Trustinah, Iswanto R, Didik H. 2014. Vima 2 dan Vima 3, Varietas Kacang Hijau Hasil Tinggi, Umur Genjah dan Masak Serempak. Prosiding 
Seminar Hasil Penelitian Tanaman

Aneka Kacang dan Umbi

729-739.

http://balitkabi.litbang.pertanian.go.i

d/wp-content/uploads/2015/05/729-

740_Trustinah-1.pdf

Chip Tebu (Saccharum officinarum L.).

Agroekoteknologi, 3(2), 458-464. 